\title{
DIPLOMASI PUBLIK INDONESIA MELALUI KONTINGEN GARUDA/ UNIFIL TENTARA NASIONAL INDONESIA DI LEBANON SELATAN
}

\author{
Angga Nurdin Rachmat \\ Jurusan Hubungan Internasional, Universitas Jenderal Achmad Yani \\ Email : angganr16@gmail.com
}

\begin{abstract}
Abstrak
Indonesia telah menjadi salah satu negara yang sangat aktif dalam pengiriman pasukan penjaga perdamaian PBB. Hal ini terbukti dari banyaknya kontingen yang dikirimkan baik berupa pasukan penjaga perdamaian maupun personil dalam misi pengawasan. Indonesia dalam hal ini mendasarkan keikutsertaan dalam pasukan penjaga perdamaian kepada pembukaan UUD 1945. Namun, selain itu pengiriman pasukan ini juga ditujukan untuk membawa Indonesia lebih dekat kepada masyarakat di negara lain, khususnya di negara dimana pasukan tersebut ditempatkan. Oleh karena itu tulisan ini akan melakukan pembahasan mengenai keberadaan dari pasukan penjaga perdamaian PBB asal Indonesia yang tergabung dalam UNIFIL yang juga membawa misi diplomasi publik kepada masyarakat di Lebanon maupun kepada kontingen UNIFIL lainnya. Tujuan dari tulisan ini adalah untuk menganalisis praktek diplomasi publik yang dijalankan oleh pasukan penjaga perdamaian Indonesia yang tergabung dalam UNIFIL.
\end{abstract}

Kata-kata Kunci : diplomasi publik, TNI, UNIFIL, Lebanon Selatan

\begin{abstract}
Indonesia has signed up as an active state in the peacekeeping force of the United Nations. This is evidenced by the delivery of a variety of contingent both on peacekeeping missions and delivery personnel as supervisors For Indonesia itself sending troops under the UN flag is an implementation of the constitutional mandate. But besides that sending troops under the UN flag is an effort to bring Indonesia to the public in other countries, particularly in countries where Indonesian troops stationed as part of a UN peacekeeping force. Therefore, this paper seeks to discuss the existence of Indonesian peacekeepers who are members of the United Nations Interim Forces in Lebanon ( UNIFIL) in carrying out the practice of public diplomacy of Indonesia to the community in Lebanon as well as a contingent of UN troops from other countries. This paper uses a descriptive analysis of the practice of public diplomacy conducted by peacekeepers Indonesia joined in UNIFIL
\end{abstract}

Keywords : public diplomacy, Indonesia Armed Forces, UNIFIL, South Lebanon.

Perdamaian dunia merupakan tanggung jawab dari seluruh negara maupun manusia yang tinggal didalamnya. Bagi bangsa Indonesia kontribusi dalam misi perdamaian yang digelar oleh PBB tidak dapat dilepaskan dari idealisme bangsa Indonesia untuk turut serta dalam menciptakan perdamaian dunia seperti yang tertuang dalam Pembukaan UUD 1945. Disamping itu platform politik luar negeri bebas aktif memberikan dorongan agar Indonesia terlibat secara aktif untuk ikut serta dan berkontribusi bagi upaya perdamaian di seluruh dunia. Indonesia sendiri pertama kali melakukan pengiriman pasukan penjaga perdamaian pada tahun 1957 ke wilayah Sinai di Mesir untuk menengahi konflik yang terjadi antara negara-negara Arab dengan Israel. Kehadiran Indonesia dalam operasi 
perdamaian yang digelar secara internasional pada masa tersebut memiliki arti penting sebagai implementasi dari nilai politik luar negeri yang dimiliki oleh Indonesia kepada dunia.

Arti penting pengiriman pasukan dalam misi perdamaian PBB juga terkait dengan pendekatan terhadap masyarakat di negara dimana misi tersebut dilaksanakan. Kondisi ini terkait dengan tugas yang diemban tidak dapat dilepaskan dengan interaksi diantara pasukan TNI dengan masyarakat dimana mereka ditempatkan.Saat ini, sebagian besar pasukan Indonesia, yakni lebih dari 1.000 personil, tergabung dalam misi pemeliharaan perdamaian PBB di Lebanon (UNIFIL), dan sisanya dikirim ke Republik Demokratik Kongo (MONUC), Darfur (UNAMID), Sudan (UNMIS), Nepal (UNMIN) dan Liberia (UNMIL) ${ }^{1}$. Hal ini menunjukan bahwa Indonesia sangat aktif dalam turut berperan serta dalam misi perdamaian khususnya yang dilaksanakan dibawah payung PBB.

$$
\text { Indonesia menyadari bahwa }
$$
keterlibatan dalam misi perdamaian PBB merupakan sebuah hal yang sangat essensial

${ }^{1}$ Kartini, Indira, 2012. Peran Indonesia dalam Misi Pemeliharaan Perdamaian PBB Jurnal Pertahanan, 2, 2 , hal. 127-150 bagi implementasi politik luar negerinya, maka untuk lebih menguatkan eksistensi pasukan perdamaian Indonesia, diterbitkan Peraturan Presiden Nomor 85 Tahun 2011 tentang Tim Koordinasi Misi Pemeliharaan Perdamaian. Dalam rapat tersebut membahas berbagai aspek antara lain keperluan pasukan, legalisasi pemberangkatan dan pendanaan pasukan, serta kemungkinan penarikan pasukan. Keberadaan TKMPP sangat penting terutama dalam mewujudkan Vision 4.000 Peacekeepers. Diharapkan pengiriman pasukan perdamaian Indonesia dapat terus bertambah dan nama Indonesia sebagai penyumbang pasukan untuk pemeliharaan perdamaian dunia semakin tersohor ${ }^{2}$.

Eksistensi Indonesia dalam upaya pemeliharaan perdamaian yang ditunjukan dengan jumlah pengiriman pasukan penjaga perdamaian menempatkan Indonesia diposisi yang sangat strategis dalam politik internasional. Karena tidak dapat dipungkiri bahwa saat ini negara-negara besar seperti AS maupun negara-negara di Eropa tidak lagi memiliki kontribusi signifikan dalam misi perdamaian khususnya dalam pengiriman pasukan dibawah mandat PBB,

2 Ariestianti, Benedicta Trixie, 2014, TNI dan Perwujudan Perdamaian Dunia", Majalah Wira, 50, 34 hal. 15-23. 
khususnya pasca berakhirnya perang dingin. Kondisi ini tentu akan memberikan keuntungan tersendiri bagi Indonesia khususnya dalam upaya untuk menunjukan eksistensi khususnya dalam aktivitas yang berada dalam ruang lingkup PBB sebagai organisasi yang memiliki peran signifikan dalam perdamaian dunia. Eksistensi Indonesia dalam misi perdamaian PBB dapat dilihat dari ditempatkannya Indonesia sebagai peringkat ke 17 negara Penyumbang Pasukan/Polisi (Troops/Police Contributing Country), dengan jumlah personil sebanyak 1.618 personil. Dengan jumlah pasukan terbesar tergabung pada misi di Lebanon Selatan dibawah United Nation Interim Forces in Lebanon ( UNIFIL) yang saat ini mencapai 1.248 Pasukan ${ }^{3}$.

Keberadaan pasukan TNI di luar negeri dalam misi perdamaian secara tidak langsung merupakan representasi dari Indonesia sebagai sebuah negara. Keberadaan dari pasukan TNI sebagai bagian dari misi perdamaian PBB telah membuka sebuah peluang besar untuk menjembatani konektivitas sosial antara TNI sebagai representasi dari Indonesia dengan masyarakat dan kontingen angkatan

\footnotetext{
3"Partisipasi Indonesia dalam Pasukan Misi Perdamaian PBB", http://www.deplu.go.id/Pages/IIssueDisplay.aspx?ID $\mathrm{P}=10 \& \mathrm{l}=\mathrm{id}$
}

bersenjata dari negara lain yang tergabung dalam misi PBB tersebut. Salah satu wilayah dimana pasukan TNI secara reguler ditempatkan adalah di Lebanon Selatan, dimana dalam upaya pemeliharaan perdamaian pasukan TNI memiliki kesempatan untuk berinteraksi langsung dengan masyarakat lokal maupun dengan kontingen pasukan penjaga perdamaian dari negara lain.

Kesempatan untuk berinteraksi dengan masyarakat lokal di Lebanon Selatan dimanfaatkan dengan baik oleh TNI. Interaksi yang dilakukan oleh TNI dengan masyarakat di Lebanon Selatan menghasilkan sebuah penerimaan yang sangat baik terhadap keberadaan pasukan TNI di wilayah tersebut. Upaya untuk mendapatkan penerimaan serta pengelolaan terhadap interaksi tersebut menjadi sebuah fenomena tersendiri baik dikalangan kontingen UNIFIL maupun masyarakat Indonesia. Fenomena tersebut terkait dengan sulitnya kontingen UNIFIL dari negara lain untuk dapat diterima secara baik serta oleh masyarakat di Lebanon Selatan. Merujuk kepada fenomena tersebut, memunculkan TNI yang tengah bertugas sebagai bagian dalam misi perdamaian PBB menjadi sebuah modal bagi praktek diplomasi publik, dimana kalangan militer saat ini telah 
meningkatkan kemampuan diplomatik, dan berupaya untuk meningkatkan kemampuan diplomatik secara berkelanjutan ${ }^{4}$. Diplomasi publik secara umum hanya dipahami dengan menggunakan berbagai instrumen dan aktor yang terkait dengan masyarakat sipil, padahal dalam hal ini diplomasi publik dapat dilakukan melalui instrumen militer.

\section{Melalui fenomena Kontingen TNI} yang tergabung dalam UNIFIL membuat keberadaan dari militer dalam diplomasi publik Indonesia tidak dapat dikesampingkan. Dengan demikian, tulisan ini membahas mengenai capaian atau tujuan yang ingin dicapai terkait keberadaan TNI dalam praktek diplomasi publik Indonesia khususnya di Lebanon Selatan. Penelitian ini didasarkan kepada sebuat pertanyaan utama mengenai agenda apa yang diusung oleh Indonesia dalam diplomasi publik melalui Kontingen Garuda/UNIFIL TNI di Lebanon Selatan?.

Tulisan ini dilakukan dengan menggunakan metode kualitatif yang dilakukan untuk mencari makna dibalik diplomasi publik yang dilakukan oleh Kontingen Garuda TNI dalam misi

\footnotetext{
${ }^{4}$ Carroll, Chad G, 2007, "The US Army Public Diplomacy Officer : Military Public Affairs Officers Roles in the Global Information Environment", Tesis, Universitas North Carolina, hal 3
}

perdamaian di Lebanon Selatan. Data pendukung dalam tulisan ini didapatkan dengan menggunakan studi litelatur terhadap berbagai dokumen yang memuat data mengenai teori dan praktek diplomasi publik serta data mengenai aktivitas dari Kontingen Garuda/UNIFIL TNI di Lebanon Selatan. Pembahasan dalam tulisan ini akan dilakukan dengan menganalisis pemulihan citra Indonesia dimata dunia, pengenalan budaya Indonesia dan memperkenalkan nilai-nilai yang dimiliki oleh masyarakat Indonesia sebagai agenda yang ingin disampaikan dalam diplomasi publik yang dijalankan oleh Kontingen Garuda/UNIFIL TNI dalam misi perdamaian di Lebanon Selatan.

\section{Kontingen TNI di Lebanon Selatan Dalam Praktek Diplomasi Publik Indonesia}

Perkembangan diplomasi saat ini tidak lagi menjadi aktvitas yang dimonopoli oleh para diplomat, dimana seiring dengan perkembangan dinamika politik internasional serta perkembangan teknologi memunculkan aktor-aktor serta metode baru dalam melakukan praktek diplomasi. Diplomasi publik hadir menjadi salah satu metode yang saat ini digunakan oleh berbagai negara dalam rangka mencapai 
berbagai tujuan dan agenda dalam politik luar negerinya yang berfokus kepada masyarakat di negara lain sebagai objeknya melalui pendekatan-pendekatan secara psikologis. Merujuk kepada definisi yang diberikan oleh Jarol B. Mainheim, diplomasi publik memiliki arti sebagai usaha sebuah negara untuk mempengaruhi opini publik maupun pemimpin dinegara lain dengan maksud untuk mempermudah pencapaian tujuan dari kebijakan luar negerinya ${ }^{5}$.

Bagi Indonesia, keberadaan pasukan TNI sebagai bagian dari UNIFIL diposisikan sebagai implementasi dari platform kebijakan luar negeri bebas aktif. Kontribusi Indonesia melalui keterlibatan TNI yang menjadi bagian dari kotingen UNFIL adalah bentuk dari implementasi keaktifan Indonesia untuk ikut serta dalam setiap upaya menciptakan perdamaian dunia. Meskipun memiliki tujuan kebijakan luar negeri yang mulia, namun resistensi dalam implementasi kebijakan luar negeri bebas aktif tersebut senantiasa tidak terlepas dari resistensi baik oleh negara maupun khususnya masyarakat di negara sasaran. Dalam diplomasi publik, masyarakat baik dalam konteks individu maupun kelompok

\footnotetext{
${ }^{5}$ Mainheim, Jarol B., 1990, Strategic Public Diplomacy : The Evolution of Influence, Oxford University Press, hal. 4.
}

dapat memberikan inisiatif kepada kebijakan pemerintah dan termasuk didalamnya aktivitas yang seharusnya dapat membentuk opini di negara lain ${ }^{6}$. Dalam hal ini kelompok masyarakat, bahkan individu diberikan keleluasaan untuk menjalankan aktivitas terkait dengan usaha untuk mendiseminasikan pengaruh, khususnya kepada masyarakat di negara lain. Upaya yang dilakukan tidak lain merupakan sebuah cara untuk mempermudah masuknya kebijakan sebuah negara ke negara lain. Upaya ini diperlukan untuk memininalisir resistensi dari masyarakat di negara tujuan terhadap kebijakan luar negeri sebuah negara yang akan ditujuan kepada negara tujuan.

Dalam definisi yang dikemukakan oleh Gyorgy Szondi diplomasi publik berkembang seputar strategi untuk melakukan promosi dan persuasi yang sangat erat kaitannya dengan kepentingan dan impresi yang ingin ditampilkan ${ }^{7}$. Kondisi ini yang kemudian sulit untuk dilakukan melalui diplomasi formal atau resmi yang dilakukan oleh pemerintah.

${ }^{6}$ Efendi, Tonny Dian, 2011. Diplomasi Publik Jepang : Perkembangan dan Tantangan, Ghalia, hal. 4.

7 Gyorgy Szondi, Central and Eastern European Public Diplomacy A Transitional Prespective on National Reputation Management dalam P. Taylor dan N. Snow ( eds ),2009. The Routledge Handbook of Public Diplomacy, New York : Routledge. hal 303 
Kekakuan dari diplomasi formal ini, dapat dicairkan dengan menggunakan individu baik yang ditunjuk oleh negara ( duta resmi negara ) maupun dilakukan secara mandiri dengan mengedepankan people-to-people contact ( $\mathrm{P}$ to $\mathrm{P}$ ). Pentingnya people to people contact dalam diplomasi publik mampu menjembatani komunikasi antar masyarakat dari satu negara dengan masyarakat di negara lain. Keterlibatan dari masyarakat atau individu sebagai representasi negara akan mempermudah pembangunan citra positif di mata negara atau khsususnya masyarakat di negara lain. Pembangunan citra positif dalam prespektif masyarakat di negara lain menjadi tujuan utama dalam membangun kesepahaman dan saling pengertian, yang dalam konsepsi Joseph Nye Jr dikenal dengan softpower.

Dalam diplomasi publik softpower menjadi lebih penting dibandingkan dengan hardpower. Softpower dari sebuah negara dapat dimiliki melalui 3 sumber yakni budaya, nilai-nilai politik dan kebijakan luar negeri ${ }^{8}$. Kegiatan-kegiatan yang dilakukan oleh Kontingen Garuda/UNIFIL TNI tidak dapat dilepaskan dari upaya untuk membina dan memupuk soft power Indonesia.

\footnotetext{
${ }^{8}$ Nye Jr, Joseph, 2009, Soft Power: The Means to Succes in World Politics, New York : Public Affairs, hal.11.
}

Merujuk kepada sumber softpower yang dikemukakan oleh Nye, pertama budaya dimana dalam hal ini adalah budaya yang dapat menarik perhatian, simpati dari pihak lain, dalam prakteknya kontingen TNI yang bertugas di Lebanon Selatan senantiasa memperkenalkan kebudayaan nasional Indonesia kepada masyarakat di wilayah tersebut maupun terhadap kontingen lain yang tergabung dalam UNIFIL. Kedua, nilai-nilai politik dimana hal ini yang kemudian diterapkan di dalam dan di luar negeri tercermin dari kemampuan untuk melakukan pendekatan terhadap masyarakat menjadi prioritas dalam setiap kegiatan yang digelar di wilayah yang menjadi binaan mereka disamping upaya untuk memperkenalkan nilai-nilai yang dimiliki oleh masyarakat Indonesia yang tercermin dalam setiap sikap dan perilaku mereka seperti sopan satu, sikap ramah tamah dan gotong royong. Ketiga, kebijakan luar negeri dimana saat kebijakan luar negeri tersebut selalu terlegitimasi dan memiliki nilai moral terkait dengan pengiriman pasukan TNI sebagai bagian dari UNIFIL yang merupakan implementasi dari politik luar negeri bebas aktif.

\section{Misi Perdamaian Sebagai Pemulihan Citra Indonesia.}


Keterlibatan sebuah negara dalam sebuah misi perdamaian dibawah payung PBB menjadi salah satu indikator komitmen terhadap penciptaan perdamaian dunia. Dengan hal ini maka dalam interaksi internasional reputasi sebuah negara dalam bidang perdamaian akan muncul dan bahkan menguat, hal ini yang akan disematkan kepada negara tersebut dimasa yang akan datang. Bagi Indonesia perdamaian dunia merupakan sebuah amanat yang harus dijalankan sesuai dengan pembukaan UUD 1945 serta implementasi dari politik luar negeri bebas aktif.

Komitmen Indonesia dalam upaya penciptaan perdamaian dunia dapat dilihat dari keterlibatan Indonesia sejak tahun 1957 telah mendapatkan penghargaan dan pengakuan dari berbagai pihak. Kredibilitas, profesionalisme serta peran dan partisipasi aktif Indonesia dalam misi pemeliharaan perdamaian $\mathrm{PBB}$ menjadi salah satu pertimbangan semakin tingginya permintaan PBB kepada pemerintah Indonesia untuk meningkatkan kontribusi dan menempatkan personel Indonesia untuk mengisi jabatanjabatan strategis baik di misi pemeliharaan perdamaian PBB maupun pada markas besar $\mathrm{PBB}^{9}$. Hal ini menunjukan bahwa

9 Kementrian Luar Negeri Republik Indonesia, "Peran Indonesia Dalam Pasukan Misi Perdamaian masyarakat Internasional mengakui keberadaan serta keaktifan Indonesia dalam upaya untuk menciptakan dan menjaga perdamaian dunia. Pengiriman pasukan pemeliharaan perdamaian di bawah bendera PBB menunjukkan komitmen kuat bangsa Indonesia terhadap perdamaian sekaligus member arti penting dalam pelaksanaan hubungan luar negeri dan implementasi politik luar negeri bebas aktif serta meningkatkan citra Indonesia di dunia internasional. $^{10}$

Upaya ini menjadi sangat penting mengingat dalam dekade terakhir Indonesia khususnya pihak TNI tengah berada dalam sorotan masyarakat Internasional seiring dengan tuduhan pelanggaran Hak Azasi Manusia ( HAM ). Berbagai kasus telah menjadikan sebagai sorotan bagi masyarakat Indonesia seperti keterlibatan TNI dalam pelanggaran HAM saat diberlakukannya Daerah Operasi Militer di Aceh, tragedi Santa Cruz di Timor Timur ( kini Timor Lester ) dan tuduhan keterlibatan dalam berbagai penculikan aktivis selama masa rezim orde baru berkuasa. TNI kemudian senantiasa dilekatkan dengan instrumen represif dari pemerintah terhadap

PBB", www.kemlu.go.id, Selasa 4 Februari 2014, http://www.kemlu.go.id/Pages/IIssueDisplay.aspx?ID $\mathrm{P}=10 \& \mathrm{l}=\mathrm{id}$ ( diakses 23 Agustus 2014 )

${ }^{10}$ Kartini, Indira, Op.cit. 
masyarakatnya dan tidak menghormati HAM. Sorotan ini membuat citra Indonesia dan khususnya TNI terpuruk bahkan beberapa negara memutuskan untuk menghentikan pasokan persenjataan serta kerjasama pertahanan dengan Indonesia. Demikian pula dengan Indonesia berbagai tekanan senantiasa ditujukan kepada pemerintah Indonesia untuk menegakan HAM yang oleh masyarakat Internasional dijadikan sebagai salah satu indikator bagi terciptanya perdamaian dunia.

Kondisi ini tentunya perlu untuk mendapatkan perhatian dimana Indonesia harus keluar dari bayang-bayang tuduhan sebagai pelanggar HAM dan kembali menguatkan citranya dimata dunia melalui komitmen terhadap perdamaian dunia. Keterlibatan aktif Indonesia dalam Operasi Misi Perdamaian di berbagai negara. Dengan terlibat dalam operasi perdamaian, tentara Indonesia ikut melakukan proses diplomasi dan politik luar negeri RI. Atas peran perdamaian yang dijalankan, pasukan Indonesia turut menyumbang softpower berupa pencitraan baik di dunia ${ }^{11}$.

11 Agung, "Pasukan TNI untuk Perdamaian, Angkat Citra Indonesia", ugm.ac.id, Kamis 10 Oktober 2013, http://ugm.ac.id/id/berita/8311-

pasukan.tni.untuk.perdamaian.angkat.citra.indonesia diakses 27 Maret 2014.
Salah satu misi perdamaian diamana Indonesia tidak pernah absen adalah keikutsertaan dalam UNIFIL di Lebanon Selatan. Keberadaan TNI yang mewakili Indonesia dalam UNIFIL dianggap sebagai salah satu pencapaian tersendiri hal ini terkait dengan penerimaan yang diberikan oleh kedua belah pihak yang bertikai diwilayah tersebut. Dimana tidak semua negara dapat diterima oleh kedua pihak yang bertikai baik Israel maupun Hizbullah terkait dengan permasalahan keberpihakan yang senantiasa menjadi masalah pelik dalam usaha menjadi penengah pada sebuah konflik. Dalam upaya pemulihan citra Indonesia maupun TNI melalui upaya keterlibatan dalam UNIFIL bukan hanya ditunjukan kepada pihak yang bertikai maupun kontingen lain dalam UNIFIL namun juga kepada dunia Internasional.

Pembuktian mengenai kemampuan dari Kontingen Garuda/UNIFIL TNI dalam melaksanakan operasi perdamaian ditunjukan dengan relatif stabilnya wilayah yang menjadi tanggung jawabnya dari berbagai ancaman gangguan keamanan dari kedua belah pihak. Padahal kondisi yang menjadi blue line yang dikuasai oleh UNIFIL sebagai wilayah yang ditujukan sebagai sekat agar kedua pihak yang bertikai tidak dapat berhadapan langsung tersebut 
sangat berpontensi menjadi penyebab munculnya konflik kembali, karena serangan dari Hizbullah akan dilakukan di wilayah-wilayah tersebut. Kontingen UNIFIL yang berasal dari negara lain harus bekerja keras untuk mengamankan wilayah yang menjadi tanggungjawab mereka di blue line tersebut. Keberhasilan Kontingen Garuda/UNIFIL TNI dalam mengamankan wilayah blue line adalah mampu mencegah kontak senjata antara tentara Israel dan Lebanon di wilayah perbatasan Al Adeisseh pada bulan Agustus 2010 ${ }^{12}$. Keberhasilan tersebut telah mendapatkan apresiasi dari UNIFIL karena bila bentrokan tersebut terjadi maka akan sangat merugikan proses perdamaian yang telah terbangun di wilayah Lebanon Selatan.

Kondisi yang berhasil diciptakan oleh kontingen UNIFIL dari pihak TNI telah menunjukan bahwa pihak Indonesia khususnya dalam hal ini TNI memiliki kemampuan yang luar biasa dalam upaya untuk menjaga perdamaian bagi pihak yang bertikai. Hal ini tentu saja akan sedikit banyak merubah pandangan miring yang senantiasa ditujukan kepada pihak TNI

\footnotetext{
${ }^{12}$ Kol.Inf.Karmin Suharna dalam "Kontingen Garuda Dikenang Cegah Bentrokan Lebanon-Israel", nasional.republika.co.id, 19 Juni 2013, http://nasional.republika.co.id/berita/nasional/umum/ 13/06/19/moltmn-kontingen-garuda-dikenang-cegahbentrokan-lebanonisrael diakses 22 Januari 2016.
}

maupun pemerintah Indonesia sebagai pihak yang mengabaikan nilai-nilai perdamaian. Dengan memudarnya pandangan miring mengenai Indonesia maupun pihak TNI, maka dunia internasional mengakui kemampuan dari pemerintah Indonesia dan TNI dalam upaya penciptaan perdamaian seperti yang mereka tunjukan dalam misi yang dijalankan di Lebanon Selatan.

\section{Pengenalan Kebudayaan Nasional Indonesia.}

Disamping tugas pokok dan fungsi dalam menjaga perdamaian di wilayah Lebanon Selatan, Kontingen Garuda/UNIFIL TNI menjalankan misi kebudayaan. Misi kebudayaan ini diimplementasikan bersamaan dengan tugas dan fungsi sebagai pasukan penjaga perdamaian dengan memperkenalkan berbagai kesenian tradisional Indonesia kepada masyarakat di Lebanon Selatan maupun kepada sesama kontingen UNIFIL yang berasal dari negara lain. Kegiatan ini menunjukan bahwa dalam konteks diplomasi publik, Kontingen Garuda/UNIFIL TNI telah menjadi aktor yang secara jelas menjadi duta bangsa dalam memperkenalkan Indonesia dan kebudayaannya kepada masyarakat luas. 
Upaya untuk memperkenalkan budaya Indonesia di Lebanon Selatan baik kepada masyarakat di wilayah tersebut maupun kepada sesama kontingen dalam UNIFIL dilakukan dengan menggelar acara "Indonesia Night". Dalam acara tersebut nuansa khas budaya nasional Indonesia dimunculkan dengan pemasangan gambar wayang serta penggunaan baju nasional Batik sebagai busana resmi panitia. Atraksi Debus, tari Poco-Poco, kolaborasi Rampak Gendang dengan Tari Saman dan juga Angklung $^{13}$ yang merupakan sebagian kecil dari kebanggan dalam bidang kesenian yang dimiliki oleh Indonesia.

Pengenalan kebudayaan Indonesia oleh Kontingen Garuda/UNIFIL TNI ini dilakukan sebagai upaya untuk mendekatkan sesama kontingen maupun masyarakat di Lebanon Selatan dengan Indonesia. Upaya ini menjadi sangat penting mengingat keberadaan dan eksistensi Indonesia sebagai sebuah negara masih belum banyak diketahui secara luas. Kondisi ini terbukti dengan lebih dikenalnya Pulau Bali sebagai sebuah destinasi wisata secara Internasional dibandingkan dengan Indonesia sebagai

13 Website TNI AD, "Kontingen Garuda UNIFIL Perkenalkan Kebudayaan Nasional dalam Indoensia Night”, tniad.mil.id, 17 Februari 2014, http://www.tniad.mil.id/index.php/2014/02/kontingen -garuda-unifil-perkenalkan-kebudayaan-nasionaldalam-indonesia-night/ diakses 29 Agustus 2014. sebuah negara, dimana Indonesia identik hanya dengan Pulau Bali saja. Pandangan ini yang kemudian berusaha diubah, yang salah satunya adalah dengan menggunakan berbagai mekanisme promosi kebudayaan yang salah satunya adalah kegiatan yang digelar oleh Kontingen Garuda/UNIFIL TNI tersebut.

Melalui pengenalan kebudayaan ini disamping untuk memperkenalkan Indonesia, juga sebagai instrumen untuk menjembatani antara masyarakat Indonesia dengan masyarakat di Lebanon Selatan dan masyarakat Internasional. Hal ini dapat membentuk opini atau pendapat umum baik pada level nasional yang dalam hal ini adalah masyarakat di Lebanon Selatan maupun masyarakat Internasional yang direpresentasikan melalui UNIFIL, dengan harapan bahwa pendapat umum ini dapat mempengaruhi para pengambil keputusan pada pemerintah atau organisasi internasional $^{14}$. Dengan dikenalnya Indonesia sebagai negara dengan kebudayaan yang beragam dan menarik, maka Indonesia dalam kaitan dengan hal ini telah mendapatkan keuntungan karena berhasil memupuk softpower dalam

\footnotetext{
14 Warsito, Tulus dan Kartikasari, Wahyuni, 2007, Diplomasi Kebudayaan : Konsep dan Relevansi Bagi Negara Berkembang Ombak, hal. 5.
} 
percaturan politik internasional pada umumnya maupun dalam skala regional dikawasan Timur Tengah pada khususnya.

\section{Implementasi Nilai-Nilai Bangsa}

Indonesia Dalam Proses Perdamaian di

\section{Lebanon Selatan}

Kontingen Garuda/UNIFIL TNI dalam menjalankan tugas pokok dan fungsinya dalam menjaga perdamaian di wilayah Lebanon Selatan senantiasa dilandasi oleh nilai-nilai yang dimiliki oleh masyarakat Indonesia. Nilai-nilai bangsa Indonesia merupakan jati diri bangsa Indonesia yang tercermin dalam sikap dan perilaku yang menjunjung tinggi sikap saling menghormati, ramah, sopan satun, musyawarah dalam menyelesaikan permasalahan serta semangat gotong royong. Meskipun berada dibawah mandat PBB yang mengharuskan semua pasukan yang tergabung dalam misi untuk bertindak dalam koridor yang telah diatur, namun perilaku maupun sikap yang ditunjukan oleh pasukan TNI yang berada di Lebanon Selatan tetap sebagaimana mereka ketika sedang berada di dalam negeri baik dalam menghadapi pihak yang bertikai, sesama kotingen UNIFIL maupun dengan masyarakat yang berada di wilayah yang menjadi tanggungjawabnya.
Kondisi tersebut tidak akan mampu diperoleh tanpa adanya kelebihan yang dimiliki oleh Kontingen Garuda/UNIFIL TNI. Kelebihan tersebut adalah bagaimana kemudian Kontingen Garuda/UNIFIL TNI dapat diterima dengan baik oleh penduduk dan membangun kedekatan dengan mereka di wilayah tersebut dibandingkan dengan kontingen dari negara-negara lain. Pasukan Indonesia bisa sangat diterima oleh masyarakat Lebanon itu disebabkan karena beberapa kelebihan yang tidak dimiliki oleh pasukan dari negara-negara lainnya. Seperti misalnya dalam hal sopan santun, dimana setiap bertemu dengan penduduk, pasukan Indonesia selalu tersenyum dan menyapa. Jika mengendarai kendaraan tidak ugalugalan melainkan sesuai dengan aturan yang telah ditetapkan oleh PBB. ${ }^{15}$

Dalam tugas pokok dan fungsi yang diemban oleh Kontingen Garuda/UNIFIL TNI yakni melakukan upaya peacebuilding, rekonstruksi wilayah paska konflik pun menjadi salah satu tugas yang harus dijalankan. Dalam kegiatan rekonstruksi ini, Kontingen Garuda/UNIFIL TNI menggunakan metode gotong-royong seperti yang dilakukan di Indonesia dengan

\footnotetext{
15 Hapsoro, Bagus, 2010, UNIFIL Potret Keberhasilan Pasukan Indonesia di Lebanon, Tabloid DIplomasi,.30, Tahun III, hal. 6.
} 
melibatkan masyarakat dalam proses pembangunan berbagai sarana dan prasarana publik yang hancur akibat perang. Dengan melibatkan masyarakat dalam kegiatan yang dilakukan maka akan menjadi jembatan untuk dapat mendekatkan diri dengan masyarakat. Hal ini juga dilakukan untuk memupuk rasa memiliki dari masyarakat terhadap fasilitas yang dibangun atau diperbaiki sehingga masyarakat diwilayah tersebut akan ikut menjaga dan memelihara fasilitas tersebut. Karena di wilayah dimana kontingen lain melakukan rekonstruksi masyarakat cenderung mengabaikan fasilitas yang dibangun tersebut sehingga tidak dapat dimanfaatkan secara maksimal oleh masyarakat.

Metode lain yang digunakan oleh Kontingen Garuda/UNIFIL TNI adalah dengan mengimplementasikan pembinaan wilayah pertahanan. Pembinaan wilayah pertahanan hal ini dilakukan untuk memudahkan pengawasan serta penguasaan kondisi geografis maupun kondisi sosial, ekonomi dan kultural dari wilayah yang menjadi tanggung jawab Kontingen Garuda/UNIFIL TNI di Lebanon Selatan. Hal ini dilakukan dengan melakukan pendekatan kepada masyarakat. Keberhasilan tugas yang dilaksanakan oleh TNI bukan karena peralatan utama sistem senjata yang dibawanya, namun lebih dikarenakan kemampuan untuk melakukan pembinaan teritorial dengan mengajak masyarakat untuk berdamai dan mendukung proses perdamaian yang sedang dilaksanakan ${ }^{16}$. Pendekatan ini dilakukan dengan ikut serta dalam berbagai kegiatan yang dilakukan oleh masyarakat sehari-hari atau dengan mengikutsertakan masyarakat dalam kegiatan TNI. Pasukan TNI yang tergabung dalam Kontingen Garuda/UNIFIL TNI tidak segan-segan untuk berbaur dengan masyarakat atau karena sebagian besar anggota kontingen garuda beragama islam, mereka pun ikut dalam kegiatankegiatan keagamaan di wilayah tersebut karena masyarakat lokal didominasi oleh masyarakat muslim.

Dengan menerapkan berbagai nilainilai yang dimiliki oleh bangsa Indonesia dalam kegiatan yang dilakukan terkait dengan upaya menjalankan tugas dan fungsi sebagai bagian dari pasukan penjaga perdamaian PBB di Lebanon Selatan terlihat bahwa kontingan Garuda yang berasal dari Indonesia memiliki keistimewaan tersendiri baik dimata masyarakat maupun diantara sesama kotingen yang tergabung dalam

\footnotetext{
${ }^{16}$ Supiadin A.S, 2009, Meningkatkan Peran TNI Pada Misi Pemeliharaan Perdamaian Dalam Mendukung Tugas Pokok, Jurnal Yudhagama, 82, 29 hal. 14-27.
} 
UNIFIL. Kondisi ini yang menunjang keberhasilan dari pelaksanaan tugas pokok dan fungsi dari kontingen garuda dalam misi perdamaian di Lebanon Selatan. Disamping itu hal ini memiliki dampak yang sangat signifikan terhadap citra positif Indonesia yang dapatkan dari nilai-nilai yang telah diimplementasikan oleh pasukan TNI di Lebanon Selatan. Citra positif ini dibuktikan dengan penerimaan yang baik dari masyarakat di wilayah Lebanon Selatan terhadap pasukan TNI. Pasukan TNI senantiasa mendapatkan apresiasi dari masyarakat melalui tercemin dari mudahnya masyarakat di Lebanon Selatan dalam menerima keberadaan pasukan TNI, sehingga dalam beberapa kesempatan pasukan TNI yang bertugas di wilayah tersebut senantiasa mendapatkan undangan untuk menghadiri berbagai acara yang diadakan oleh masyarakat.

\section{Kesimpulan.}

$$
\begin{aligned}
& \text { Diplomasi Publik yang saat ini } \\
& \text { tengah gencar dijalankan oleh berbagai } \\
& \text { negara di dunia dengan beragam variasi } \\
& \text { instrumen maupun metode membuat } \\
& \text { Indonesia perlu untuk menyadari arti } \\
& \text { penting dari praktek diplomasi publik. Salah } \\
& \text { satu praktek diplomasi publik yang } \\
& \text { dilakukan oleh Indonesia adalah dengan }
\end{aligned}
$$

pengiriman pasukan penjaga perdamaian dibawah payung PBB. Pengiriman pasukan penjaga perdamaian ini tidak hanya memberikan signifikansi terhadap keamanan dan perdamaian dunia yang dapat meningkatkan citra sebuah negara, namun juga dalam upaya untuk memperkenalkan diri di negara dimana misi tersebut dijalankan serta kepada negara-negara lain yang tergabung dalam pasukan penjaga perdamaian PBB.

Berbagai kegiatan yang dilakukan oleh Kontingen Garuda/UNIFIL TNI di Lebanon Selatan secara tidak langsung merupakan bagian dari praktek softpower Indonesia yang masuk dalam kategori diplomasi publik. Hal ini terlihat dari bagaimana respon negara lain yang berada dalam kontingen Garuda tersebut maupun masyarakat diwilayah dimana mereka ditempatkan mulai mengenal dan memberikan apresiasi positif terhadap Indonesia. Keberadaan kontingen Garuda yang tergabung dalam UNIFIL menjadi fenomena tersendiri dalam praktek diplomasi publik yang dilakukan oleh Indonesia, hal ini terkait dengan keterlibatan TNI sebagai unsur militer yang berfungsi menjalankan praktek diplomasi publik dalam penyampaian agenda disamping tugas pokok dan fungsi sebegai bagian dari 
pasukan penjaga perdamaian PBB. Sementara negara-negara lain lebih menggunakan aktor sipil dalam mempraktekan diplomasi publik yang ditujukan kepada masyarakat di negara lain. Oleh karena itu Indonesia dapat memanfaatkan serta memaksimalkan Kontingen Garuda/UNIFIL TNI maupun kontingen lain yang tergabung dibawah bendera Pasukan Penjaga Perdamaian PBB sebagai instrument diplomasi publik di negara lain.

\section{Daftar Pustaka}

"Partisipasi Indonesia dalam Pasukan Misi Perdamaian PBB", Website Kemenlu, Rabu 16 September 2009, http://www.deplu.go.id/Pages/IIssu eDisplay.aspx?IDP=10\&l=id

Agung, "Pasukan TNI untuk Perdamaian, Angkat Citra Indonesia", ugm.ac.id, Kamis 10 Oktober 2013, http://ugm.ac.id/id/berita/8311pasukan.tni.untuk.perdamaian.angk at.citra.indonesia

Bagus Hapsoro, "UNIFIL Potret Keberhasilan Pasukan Indonesia di Lebanon", Tabloid DIplomasi, No.30 Tahun III 15 April-14 Mei, 2010 .

Carroll, Chad G., 2007, "The US Army Public Diplomacy Officer : Military Public Affairs Officers Roles in the Global Information Environment", Tesis, Universitas North Carolina.
Kementrian Luar Negeri Republik Indonesia, "Peran Indonesia Dalam Pasukan Misi Perdamaian PBB", www.kemlu.go.id, Selasa 4 Februari 2014, http://www.kemlu.go.id/Pages/IIssu eDisplay.aspx?IDP=10\&l=id

Mainheim, Jarol B, 1990. Strategic Public Diplomacy : The Evolution of Influence. Oxford University Press, New York, 1990.

Nye Jr., Joseph, 2009. Soft Power : The Means to Succes in World Politics, Public Affairs, New York.

Tonny Dian Efendi, 2011, Diplomasi Publik Jepang : Perkembangan dan Tantangan, Ghalia, Bogor.

Tulus Warsito dan Wahyuni Kartikasari, Diplomasi Kebudayaan : Konsep dan Relevansi Bagi Negara Berkembang, Ombak, Yogyakarta.

Website TNI AD, “Kontingen Garuda UNIFIL Perkenalkan Kebudayaan Nasional dalam Indoensia Night", tniad.mil.id, 17 Februari 2014, http://www.tniad.mil.id/index.php/2 014/02/kontingen-garuda-unifilperkenalkan-kebudayaan-nasionaldalam-indonesia-night/

Indirana Kartini, 2012, “ Peran Indonesia dalam Misi Pemeliharaan Perdamaian PBB” Jurnal Pertahanan, Vol. 2 No. 2.

Benedicta Trixie Ariestianti, 2014 "TNI dan Perwujudan Perdamaian Dunia", Majalah Wira, Vol. 50 No. 34. 